public schools. In Argentina, comparable data are not available, but based on the Household National Survey, we calculated the global dropout rates by socioeconomic status among young people (I8-30 years old). The data showed that lower-income students had a higher global dropout rate ( 55 percent) than those in the middle-income group (40 percent) or in the high-income group (2I percent).

\section{Hierarchical Differentiation}

During the past decade, both in Argentina and Chile, the most dynamic institutions in terms of undergraduate enrollment expansion have not been top-tier institutions but, rather, nonuniversity public or private tertiary institutions and private universities.

In Argentina, although most of the undergraduate enrollment is at public universities, this sector's participation in the total enrollment has decreased by almost io percent in one decade (from 63 to 54 percent of the total undergraduate enrollment between 2005 and 2015). The highest in-

\section{Chile has rapidly improved access to higher education for students belonging to the lowest strata, surpassing Argen- tina's net enrollment rate (NER).}

crease was registered in the public and, to a lesser extent, in the private, nonuniversity tertiary sector that trains primary and secondary school level teachers and offers short vocational and technical programs. In addition, some nonselective, teaching-oriented private universities expanded their enrollment faster than elite, private institutions or public universities.

In Chile, 6I percent of the $20 \mathrm{I7}$ undergraduate enrollment was concentrated in mostly nonselective professional institutes and in independent private universities (those universities that do not belong to the selective and higherquality public and private Council of Rectors of Chilean Universities sector). At professional institutes, vocational degrees showed the highest growth rates between 2008 and 2017 . Since 2006 , and especially after the student movement of 20II, student-funding policies have promoted access to these sectors through the expansion of student loan and grant programs also covering technical education. The new gratuidad (tuition-free) law, enacted in 2016 and targeting low- and middle-income students, may also help expand the number of low-income students who have access to the least selective programs and institutions. This financial aid measure does not require students to achieve a minimum score on the national college admissions test (PSU), which is still a condition for grants and loans programs.

In sum, massification in both countries has improved the access of new generations of lower-income secondary school graduates to less selective and lower-quality programs in the public and private sectors. The vertical stratification among higher education institutions has increased as a result of a lack of communication channels and mobility pathways between them.

\section{CONCLUSION}

Given the complexities of massification and institutional differentiation in higher education, it is not possible to analyze the equity of a given system by focusing only on general policies regulating access and state or private funding mechanisms. When focusing on secondary school and undergraduate dropout rates and on the programs and institutions that lower-income students attend, striking inequalities may appear. To conduct this type of analysis, it is necessary to produce more and better indicators accounting for quantitative and qualitative transformations of the student body, as well as for the institutional stratification occurring as a result of increasingly massified and heterogeneous secondary school and higher education sectorsdevelopments that are occurring throughout Latin America. DOI: http://dx.doi.org/10.60I7/ihe.20I9.97.I0950n

\section{Development of the Credit System in Kazakhstan}

\section{ARAy Ilyassova-SChOEN FELD}

Aray Ilyassova-Schoenfeld is a postdoctoral scholar at the Graduate School of Public Policy, Nazarbayev University, Kazakhstan. E-mail: ailyassova@nu.edu.kz.

Ater the collapse of the Soviet Union in I99I, it became Aessential for Kazakhstan to increase the quality and competitiveness of its higher education. Its aim was to become a part of the European or American systems, and/ or an OECD member, in order to enhance the recognition of its researchers and faculty, and of their work. It took a long journey before Kazakhstan achieved its goals. All educational reforms in Kazakhstan, including changes in the structure or content of education, as well as credit system 
development, were issued through legislation. For example, the Law on Education (2007) specified the basic principles of the national educational policy. It also addressed issues of transition in the credit system.

The credit system at Kazakhstani universities is unique. It has evolved from a time when graduates of the Soviet educational system were required to prove their qualifications and degrees by calculating or converting their learning hours into international grading systems - the US system and later the European Credit Transfer and Accumulation System (ECTS). This was a big challenge because the Soviet system did not have any credit-based learning.

\section{History MATTERS}

The desire of a developing country to learn from advanced countries entails both borrowing and importing new ideas and policies. These processes occurred in Kazakhstan in relation to the United States and certain European countries such as Sweden and Germany. In the I990s, as a result of US engagement in different projects in Kazakhstan, Kazakhstani higher education institutions (HEIs) started implementing the American credit system. In the 2000s, the ministry of education introduced new Kazakhstani credits that differed from the US model. The main difference was in the number of hours per credit for the bachelor's, master's, and PhD programs. The current national model of credit system consists of a number of scales of evaluation. It was created in line with international standards by preserving Kazakhstan's own political, ideological, economic, social, and cultural background.

\section{LEARNING LESSONS}

After the introduction of the US credit system, HEIs in Kazakhstan looked toward Europe, exploring and identifying similarities between their system and those of European universities. By establishing a working group in response to a directive from the ministry of education, HEIs studied the policies and practices of 50 universities that implemented a credit system in the United States, Europe, and Asia. Several Kazakhstani HEIs implemented the credit system as a pilot. Some of the terminology (such as "office of the registrar") and pedagogical practices and roles such as advisers, tutors, and teachers guiding students on their independent work, were unknown to the local educational system at that time. Exploring and engaging with foreign universities allowed Kazakhstan to adopt some of their practices.

\section{Influence of the Bologna Process}

Integrating into the European educational space became a key direction of Kazakhstan's educational policy. In 20I0, the country became a member of the Bologna Process (BP). In practice, changes had already occurred before formally adhering to the Bologna Declaration. For example, in the 2003-2004 academic year, HEIs in Kazakhstan introduced the credit system and the two-level degree system as an experiment. (The adoption of ECTS and the degree system does not relate directly to the influence of the BP. It also occurred through the implementation, in Central Asia, of a number of EU programs such as the Trans-European Mobility Program for University Studies [TEMPUS], Erasmus Mundus, and Erasmus+). Finally, ratifying the Lisbon Convention in 1997 helped Kazakhstan in the process of mutual recognition of qualifications with other participating countries.

ECTS is a component of the BP, which standardizes grading systems in order to facilitate student mobility in Europe. A major benefit of joining the BP for Kazakhstan was the introduction of credit-based learning, resulting in mobility and the flexibility of learning elsewhere. Kazakhstan attempted to make a correlation between the US credit and ECTS, trying to overcome the practical and philosophical difficulties associated with developing a national model of credit system.

\section{National Model of Credit Transfer Based on ECTS}

The current Kazakhstani credit system is a combination of the American and European systems. It uses certain calculations including one ratio for the undergraduate level and another for the master's and PhD levels. In Kazakhstan, a credit consists of three components: class hours, independent work of bachelor's and master's degree students under the supervision of faculty (tutorials), and a student's independent work. For practical reasons, Kazakhstan moved toward a system under which one contact hour would be counted as a learning hour, to facilitate the return of students who had been on study abroad programs in Europe. Although this compromise represents an adjustment of the established European system, it did help institutions such as KIMEP University-which currently use the American modus operandi-to get closer to the ECTS model. Another example is Nazarbayev University (NU), which emphasizes the American model of higher education. The academic framework at NU is a hybrid between the American and the British frameworks, although the NU also complies with Bologna principles.

\section{CONCLUSION}

Kazakhstan has the ambition of bringing its higher education system at par with the developed world. Since I99I, the higher education system has been steered through a 
transition period. The Kazakhstani government has sought to align the higher education system with international standards through a series of reforms. These reforms established academic mobility, a diploma supplement, and a three-level degree system. The academic community endeavored to implement a new model of education with new terms and titles, by copying foreign experience and adapting Western models of education to the Kazakhstani context. The credit system was adjusted to facilitate mobility and the employability of its graduates abroad. Academics combined the Soviet, European, and American systems of higher education, incorporating and assimilating selected practices, while preserving national, cultural, historical, and linguistic characteristics in one national credit model customized to the national context.

\section{NEW PUBLICATIONS}

(Editor's note: We welcome suggestions from readers for books on higher education published especially outside of the United States and United Kingdom. This list was compiled by Jean Baptiste Diatta, graduate assistant at $\mathrm{CIHE}$.)

Ashwin, Paul, and Jennifer Case, eds. Higher Education Pathways: South African Undergraduate Education and the Public Good. Cape Town, SA: African Minds, 2018. pp. 298. Website: http:// www.africanminds.co.za

Bank, Leslie, Nico Cloete, and Francois van Schalkwyk, eds. Anchored in Place: Rethinking universities and development in South Africa. Cape Town, SA: African Minds, 2018. pp. 243. Website: http://www.africanminds.co.za/ dd-product/anchored-in-placerethinking-universities-and-development-in-south-africa/

Banks, James A., ed. An Introduction to Multicultural Education. New York, NY: Pearson, 2019. pp. 208. Website: http://www. mypearsonstore.com/bookstore/introduction-to-multicultural-education-9780134800363

Barkatsas, Anastasios, Nicky Carr, and Grant Cooper, eds. STEM Education: An Emerging Field of Inquiry. Boston, MA:
Brill Sense, 2019. pp. 232. Website: https://brill.com/view/ title/54193

Beaudry, Catherine, Johann Mouton, and Heidi Prozesky. The Next Generation of Scientists in Africa. Cape Town, SA: African Minds, 2018. pp. 207. Website: http://www.africanminds.co.za/ dd-product/the-next-generationof-scientists/

Bleiklie, Ivar, Jurgen Enders, and Benedetta Lepori, eds. Managing Universities: Policy and Organizational Change from a Western European Comparative Perspective. Cham, Switzerland: Palgrave Macmillan, 2017. pp. 329. Website: https://www.palgrave.com/ us/book/9783319538648

Chang, Da Wan, Morsjodo Sirat, and Dzulkidli Abdul Razak, eds. Higher Education in Malaysia: A Critical Review of the Past and Present for the Future. Pulau Pinang, Malaysia: Penerbit Universiti Sains Malaysia, 2019. pp 451. Website: http://www. penerbit.usm.my/index.php/ buku/288-higher-education-inmalaysia-a-critical-review-ofthe-past-and-present-for-thefuture

Cloete, Nico, Ian Bunting, and Francois van Schalkwyk. Research Universities in Africa. Cape Town, SA: African Minds, 2018. pp. 314. Website: http://www. africanminds.co.za/dd-product/ research-universities-in-africa/

Curry, Mary Jane, and Theresa Lillis, eds. Global Academic Publishing: Policies, Perspectives and Pedagogies. Bristol, UK: Blue Ridge Summit, 2018. pp. 296. Website: http://www.multilingual-matters.com/display. asp? $\mathrm{K}=9781783099221$

Deem, Rosemary, and Heather Eggins, eds. The University as a Critical Institution? Rotterdam Netherlands: Sense, 2017. pp. 238. Website: https://www. sensepublishers.com/catalogs/ bookseries/higher-educationresearch-in-the-21st-century-series/the-university-as-a-criticalinstitution/

Delisle, Jason D., and Alex Usher, eds. International Perspectives in Higher Education: Balancing Access, Equity, and Cost. Cambridge, MA: Harvard Education Press, 2019. pp. 229. Website: http://www.aei.org/publication/ international-perspectives-inhigher-education-balancing-access-equity-and-cost/

Effah, Paul. Rethinking Higher Education Governance in Ghana: Reflections of a Professional Administrator. Dakar, SN: CODESRIA 2018. pp. 136. Website: http:// www.codesria.org/carnegie/rethinking-higher-education-governance-in-ghana-reflections-ofa-professional-administrator/
Eggins, Heather, ed. The Changing Role of Women in Higher Education: Academic and Leadership Issues. Cham, Switzerland: Springer Nature, 2017. pp. 310. Website: https://www.springer. com/us/book/9783319424347

Gasu, John. Strengthening Higher Education Leadership in Africa: A Study of Ghana's Situation. Dakar, SN: CODESRIA, 2018. pp. 248. Website: http://www. codesria.org/carnegie/strengthening-higher-education-leadership-in-africa-a-study-of-ghanassituation/

Hall, Timothy, Tonia Gray, Greg Downey, and Michael Singh, eds. The Globalisation of Higher Education: Developing Internationalised Education Research and Practice. Cham, Switzerland: Springer, 2018. pp. 467. Website: https://www.springer.com/gp/ book/9783319745787\#aboutAut hors

Hoffman, Jaimie, Patrick Blessinger, and Mandla Makhanya, eds. Perspectives on Diverse Student Identities in Higher Education: International Perspectives on Equity and Inclusion. Bingley, UK: Emerald Publishing Limited, 2019. pp. 200. Website: https:// www.barnesandnoble.com/w/ perspectives-on-diverse-studentidentities-in-higher-educationjaimie-hoffman/1129108609 